\title{
THE GEOLOGY OF THE KALAHARI GEMSBOK NATIONAL PARK
}

\author{
S. J. MALHERBE
}

Geological Survey

P.O. Box 775

Upington

8800

\begin{abstract}
The floor rocks of the Kalahari Group are only known from boreholes. It consists of rocks of the Karoo Sequence with its associated intrusions of dolerite. The pre-Kalahari topography was dissected by rivers which drained in the direction of the present Botswana.

The distribution of the oldest formation of the Kalahari Group, the Wessels Formation (clayey gravel), and the overlying Budin Formation (clay) was also determined from borehole records. The Karoo Sequence was probably the source of these rocks. The overlying Eden Formation (sandstone, grit and conglomerate) had a source which could yield much sand. All these formations were deposited under fluviatile conditions.

The Mokalanen Formation (calcrete) and the Gordonia Formation (sand) indicate a change from a humid to an arid environment. The Lonely Formation (clayey diatomaceous limestone) was deposited in a lacustrine environment. It also indicates a higher rainfall in an otherwise arid period. The Goeboe Goeboe Formation consists of clay and sand in the pans and rivers.
\end{abstract}

\section{.Introduction}

Prior to 1980 virtually no geological work had been undertaken in the Kalahari Gemsbok National Park, Republic of South Africa. During the 1960's geohydrological reports covering the area had been compiled by Smit $(1962,1964)$ and some years later a report on the pre-Kalahari geology was published by Smit (1972). This was followed by a more detailed geological survey by Thomas (1981), while the present author also investigated the area during 1983.

\section{Methods}

The rock outcrops were examined in the field and indicated on aerial photographs. The information was then transferred onto maps on a scale of 1:50 000. The final map (Fig. 1) on a scale of 1:500 000 was produced from these 1:50 000 scale originals. 


\section{Geological setting}

All the rocks of the Kalahari Gemsbok National Park (KGNP) form part of the Kalahari Group. Formation names have been assigned to the various units included in this group, with each formation comprising a distinctive rock or sediment type, or combination of such types. The formations of the Kalahari Group are all present within the confines of the park, although only some form surface outcrops (Fig. 1).

The pre-Kalahari floor is only known from borehole records and consists of either dolerite or Karoo Sequence sedimentary rocks containing a thin coalbed (P. J. Smit pers. comm.).

\section{The Karoo Sequence}

This sequence consists of the Dwyka and Prince Albert Formations which are present beneath the cover of Kalahari rocks. They are difficult to separate by means of borehole samples. The Dwyka Formation was deposited during an ice age and consists of pebbles in a fine shaley matrix. A number of beds of sandstone and conglomerate - probably formed as glacial outwash - are known. The Prince Albert Formation consists of shale and was deposited as clay in a shallow sea.

Both these formations yield salty groundwater. Dolerite intruded these formations as vertical dykes or horizontal sheets.

\section{The Kalahari Group}

This group consists of the following formations:

\section{Wessels Formation}

No outcrops of this formation are present. Gravels belonging to the Wessels Formation are mentioned in the logs of some of the boreholes. Outside the park these gravels are found in the deepest portions of buried pre-Kalahari valleys.

No information about the composition of the gravels is available but it is probable that the glacial erratics of the Dwyka Formation tillite supplied much of this material.

\section{Budin Formation}

As in the case of the previous formation, no outcrops occur in the park. According to the borehole logs it consists of red clay which accumulated in pre-Kalahari river 
courses. The composition of this unit indicates that the Dwyka and Prince Albert Formations were probabily the source of the material.

\section{Eden Formation}

The Eden Formation can be seen along the present day river courses with the best exposures along the Auob River (Fig. 1).

The lithologies of the outcrops are variable, comprising red, brown, yellow, cream and green sandstones, grits and lenses of conglomerate. The sediments show a gradation downwards into the Budin Formation (as observed in boreholes) and upwards into limestone. The sandstones are very fine-grained in places. Crossbedding is rarely seen. The conglomerate is poorly rounded and consists of red sandstone pebbles in a red sandstone matrix. It appears to represent the erosion products of the older Eden Formation sandstone.

In the less-well consolidated sandstone beds an irregular interlocking network of tubes (Fig. 2), probably formed by burrowing organisms, possibly worms, are common. The material filling the tubes is identical to that constituting the surrounding

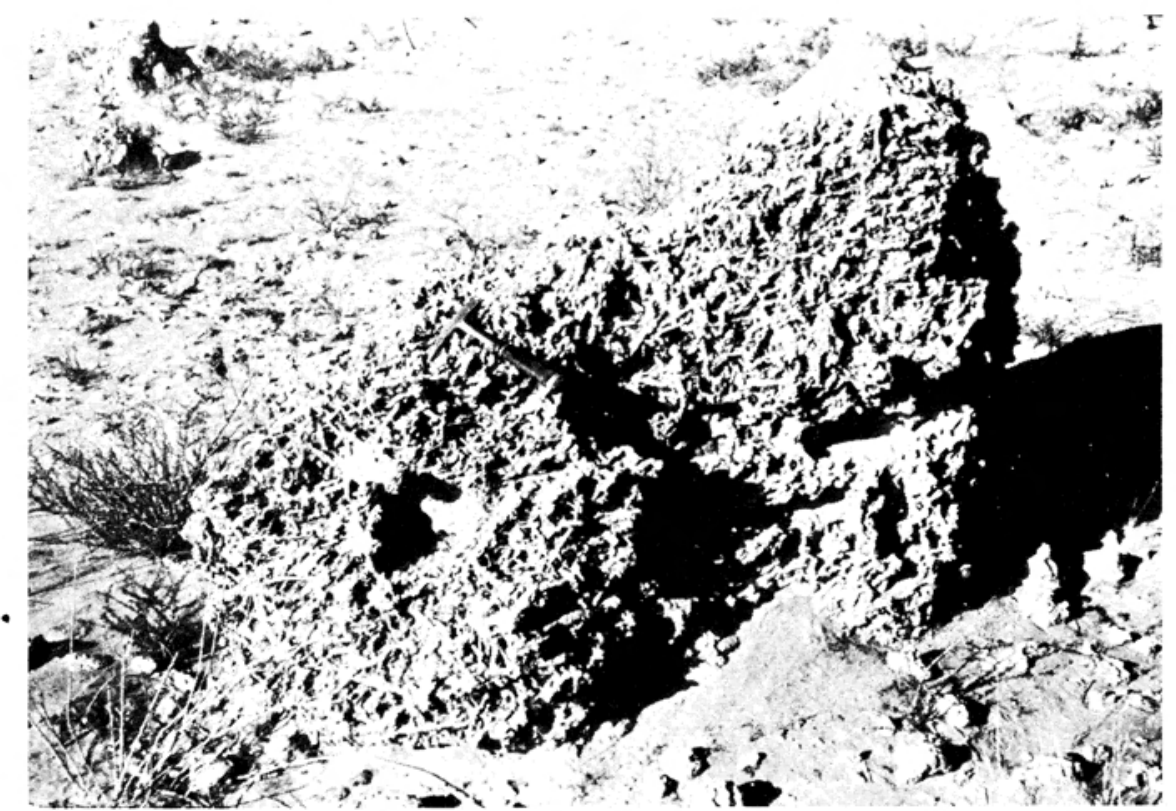

Fig. 2. An interlocking network of sandfilled tubes in the Eden Formation in the Kalahari Gemsbok National Park.

Photo: A. W. Keyser

matrix, though it is slightly better cemented with the result that the tubes weather out as positive features on bedding surfaces. Two types of hollow tubes are present. The one type shows a rim of limestone and was almost certainly formed by plants. The other may have been formed either by plant roots or burrowing organisms (Fig. 3). 


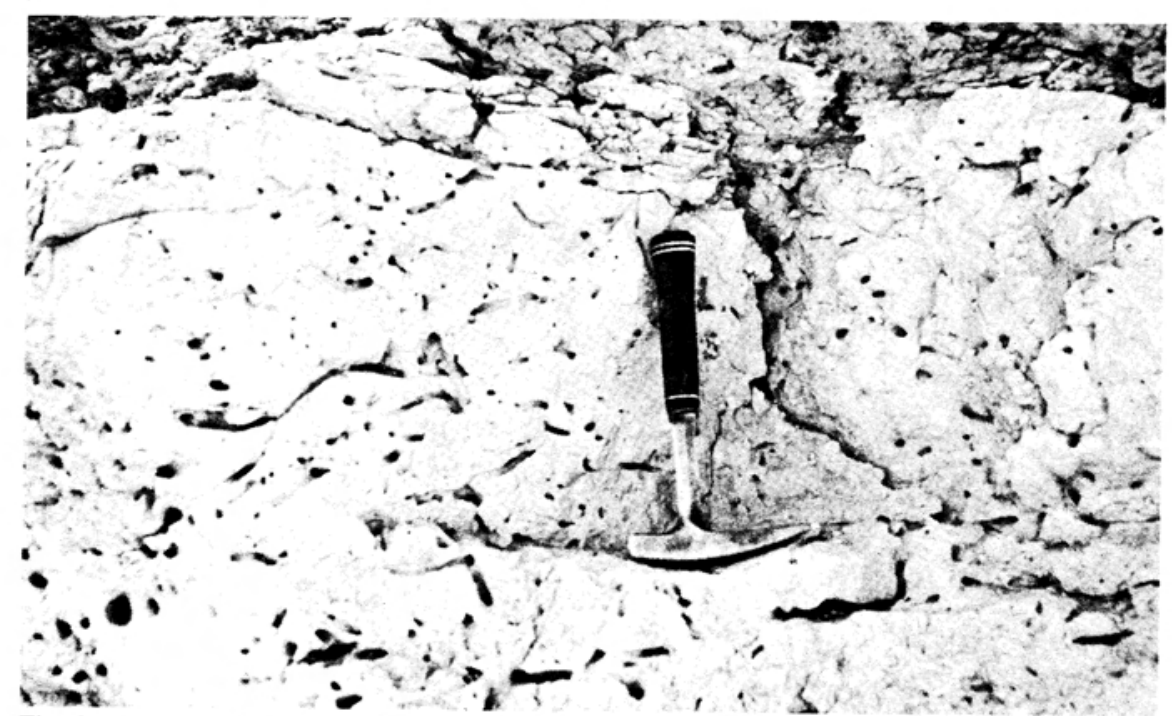

Fig. 3. Hollow tubes in the Eden Formation probably formed by plants and burrowing organisms in the Kalahari Gemsbok National Park.

Photo: A. W. Keyser

This formation was probably deposited by a braided river system on a surface of low relief.

\section{Mokalanen Formation}

The nodular and hardpan calcretes are assigned to this formation.

Three types can be recognised:

1) Fragments of the underlying Eden Formation are cemented by calcrete to form a sharpstone calc-conglomerate in places (Fig. 4). It is not continuous and may reach a thickness of two metres.

2) The second unit consists of nodular calcrete (Fig. 5) and follows on unit (1) or on the Eden Formation. Layers of hard calcrete can be seen in many localities and give rise to a prominent terrace in the topography. It is usually thicker than half a metre but seldom more than four metres.

3) The upper unit consists of hardpan calcrete (Fig. 6) with a maximum thickness of two metres. It forms when the nodular calcrete is cemented by calcrete or silcrete. A laminated rind of calcrete or silcrete may appear on the surface. It is found over most of the area and defines a fairly flat topography. As a result of silicification the hardpan calcrete is an extremely weather-resistant rock which forms a prominent terrace. Whereas the underlying fluvial formations of the Kalahari Group represent more humid conditions, the Mokalanen Formation indicates a semi-arid environment. 


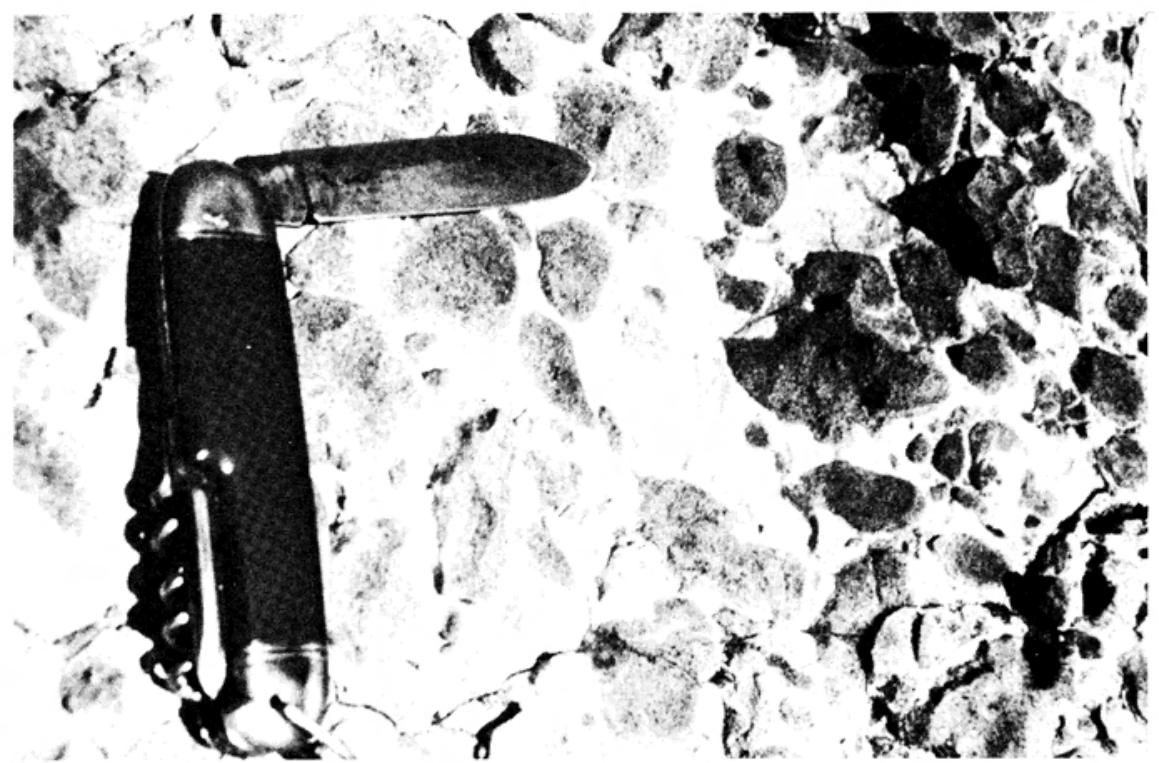

Fig. 4. Fragments of the Eden Formation cemented by calcrete in the Mokalanen Formation in the Kalahari Gemsbok National Park. Photo: A. W. Keyser

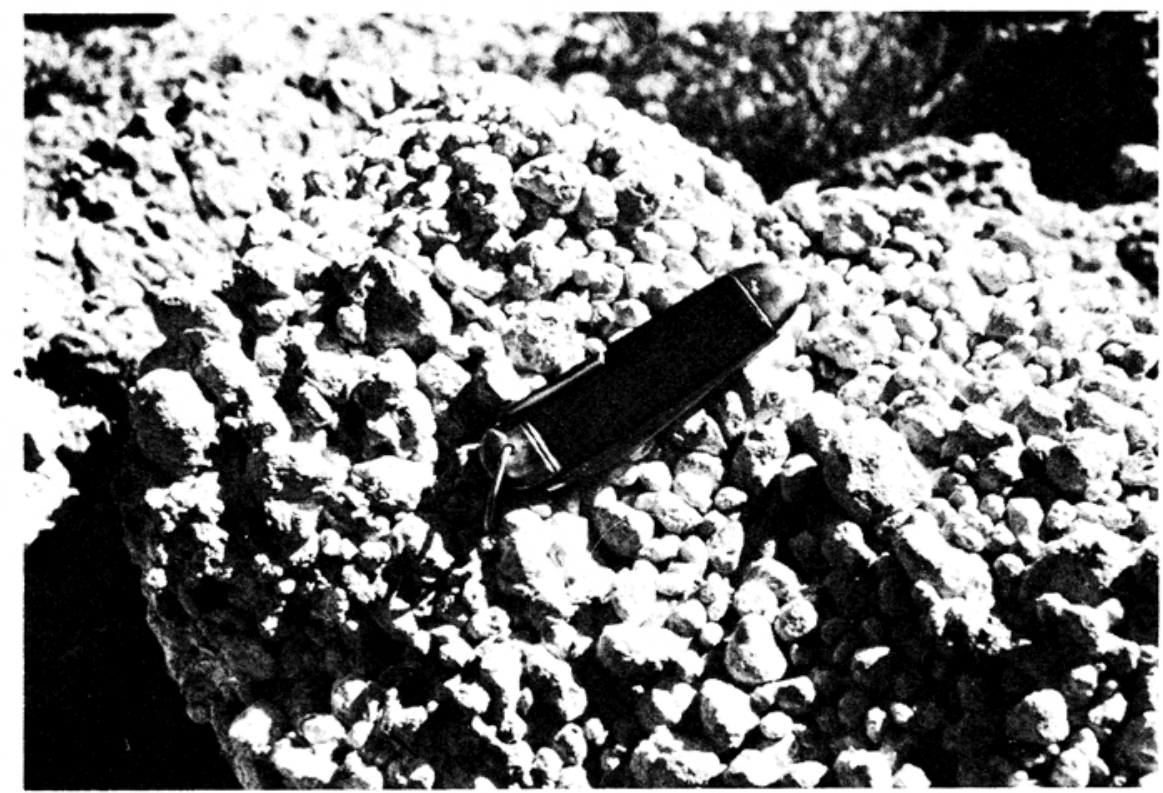

Fig. 5. Nodular calcrete in the Mokalanen Formation in the Kalahari Gemsbok National Park. Photo: A. W. Keyser 


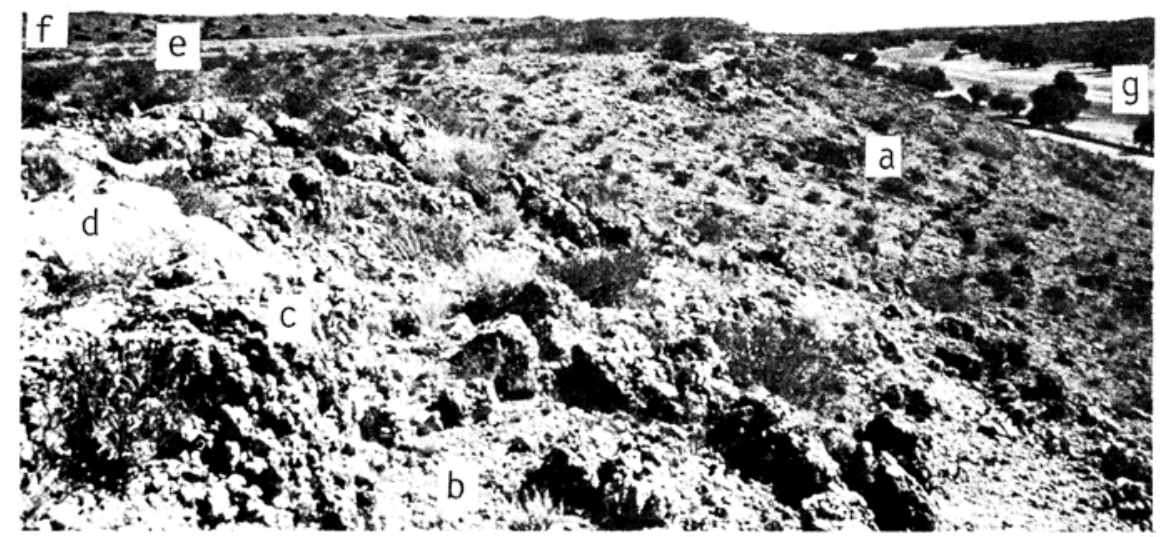

Fig. 6. A number of features are visible in this picture:

a) Reddish sandstone of the Eden Formation.

b) Nodular calcrete.

c) Hardpan calcrete.

d) Surface rind of calcrete of the Mokalanen Formation.

e) The flat surface on top of the Mokalanen Formation.

f) A sand-dune of the Gordonia Formation.

g) The river deposits of the Goeboe Goeboe Formation.

The Auob River eroded a valley which is younger than the Mokalanen Formation but older than the Gordonia Formation (Kalahari Gemsbok National Park).

Photo: A. W. Keyser

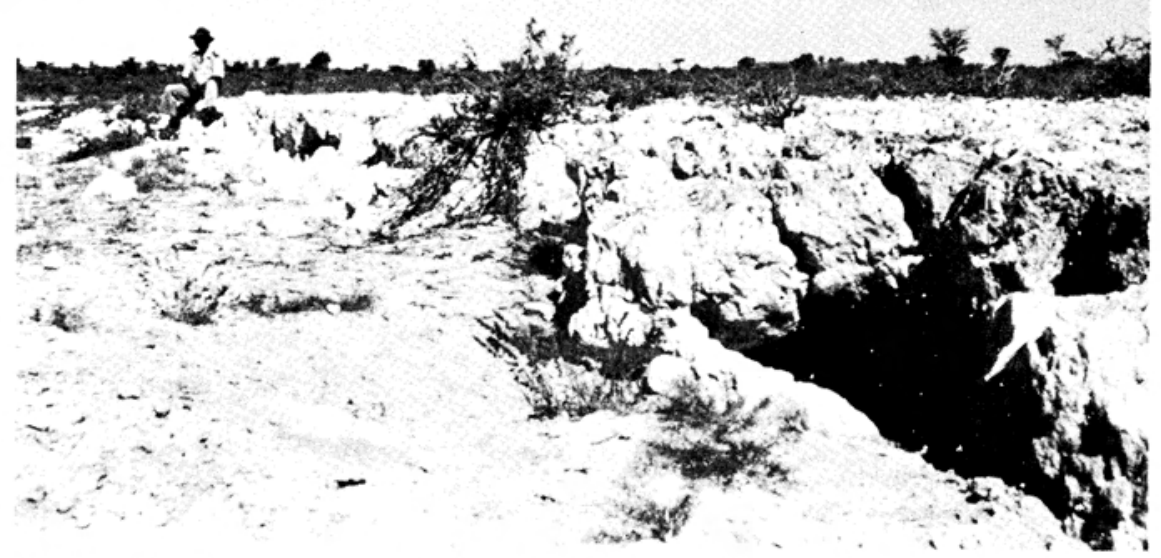

Fig. 7. The clayey diatomaceous limestone of the Lonely Formation at Bayip Pan, Kalahari Gemsbok National Park. Photo: A. W. Keyser 


\section{Lonely Formation}

The Lonely Formation consists of clayey diatomaceous limestone and is found in, and as steps along the sides of pans such as Bayip and Sewe Panne. It contains the skeletal remains of diatoms and gastropods. It is termed "tufa" by Netterberg (1980) and can be described as buff-grey in colour, quite soft and very light in weight. It has been intruded by present-day root systems and thus commonly contains many hollow tubes (Fig. 7).

Specimens of the rock were prepared by the Palaeontology Section of the Geological Survey and Dr. R. E. M. Archibald of the Council for Scientific and Industrial Research recognised the following diatom genera: Epithemia, Diploneis, Mastogloia, Pinnularia and Surirella (Fig. 8).

Thomas (1981) writes as follows about the fossils from the type area on the farm Lonely $27^{\circ} 00^{\prime} \mathrm{S}, 21^{\circ} 45^{\prime} \mathrm{E}$ : "It is always associated with pans and water courses and invariably contains diatoms and gastropods. A specimen from Lonely farm was examined by D. Jutson (personal communication). Of the macrofossils one pelecypod, Corbula africana, and one gastropod, possibly Xeroceratus damarensis, were recognised. A variety of diatoms were identified: Cymbella gastroides (Kutzing), Cymbella lanceolata (Ehrenburg), Epithemia gibba (Kutzing), Epithemia argus (Kutzing), Melosira cf. roeseana (Rabenhorst), Melosira distans (Kutzing), Diploneis sp., Fragillaria spp., Mastogloia sp., Stauroneus sp. and Synedra sp. A number of ostracods were also identified: Cypridopsis aculeata (Costa), Cypridopsis elizabethae (Sars), Gomphocythere expansa (Sars) and Gomphocythere obtusata (Sars).

Besides the ostracods, charaphyte stems and oogonia were liberated when the specimen was treated with hydrogen peroxide."

All the fossil species identified are still living forms or have been found in Quaternary sediments.

The presence of the fossils referred to above indicates that the rock formed in shallow pans with some aquatic vegetation or along sluggish-flowing rivers. Subrounded to rounded quartz grains are probably of aeolian origin. This indicates that the Lonely Formation represents a wetter period from approximately 19000 years B.P. to 12000 years B.P. (Heine 1978) in a generally dry cycle when windblown sand was present.

\section{Goeboe Goeboe Formation}

The pan and river floors are practically horizontal with sparse or no outcrop and are covered by brown to white, fine-grained sandy sediment (Fig. 6). Some pans have a white salt crust and during dry periods mud cracks and peels appear on the surface. These sediments are relatively young and some are in fact forming at present. Work by Thomas (1981) on the mineral composition indicates that quartz, calcite, montmorillonite and feldspar are the main components. 


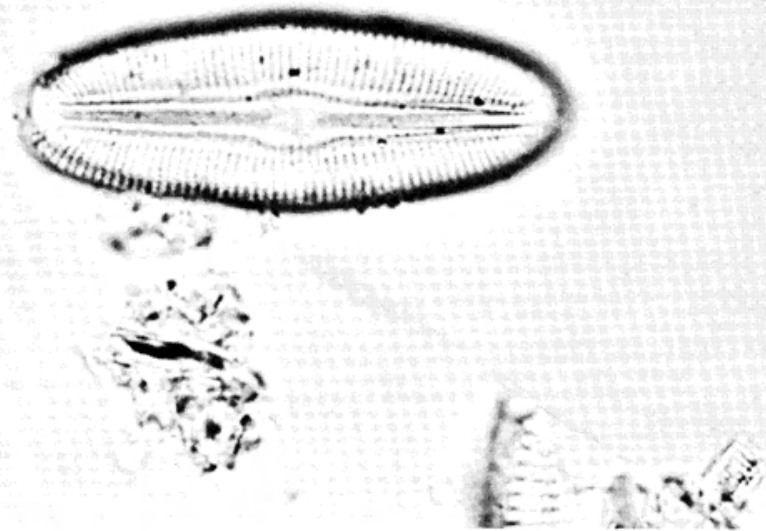

Fig. 8 (a). Frustules of diatoms from the Lonely Formation at Bayip Pan. a) Diploneis $\times$ 1000 (Kalahari Gemsbok National Park).

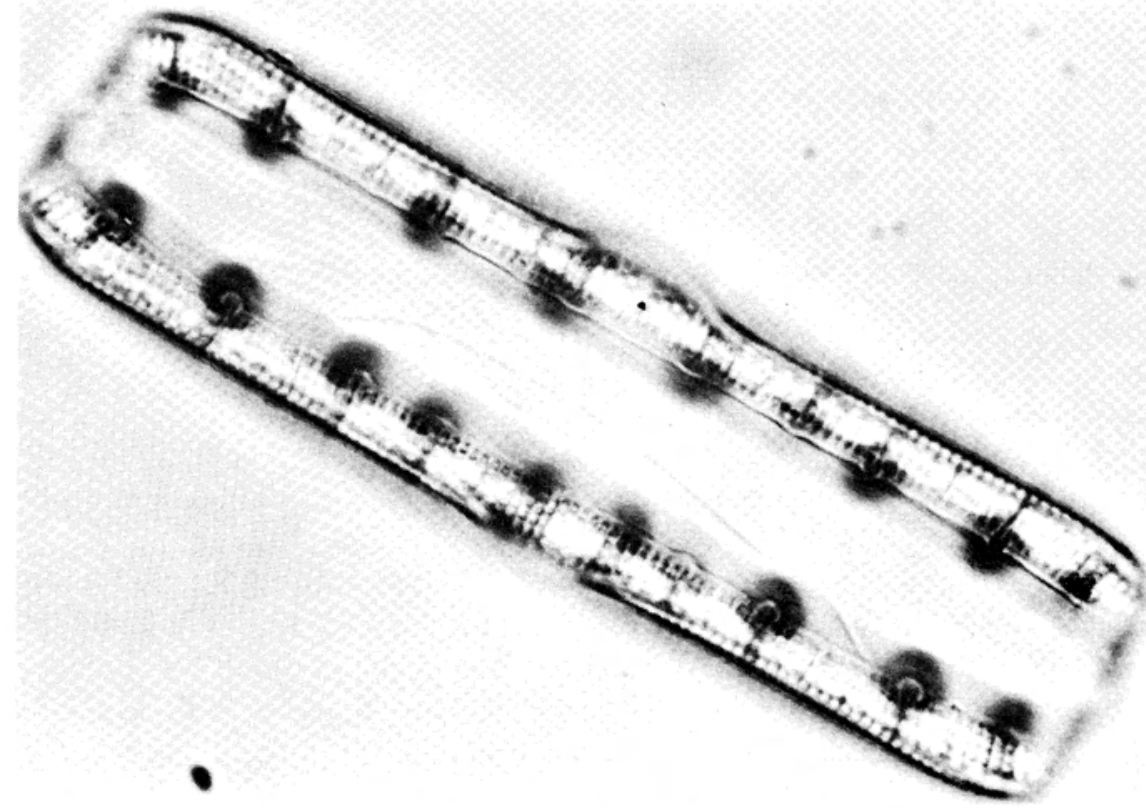

Fig. 8 (b). Epithemia $\times 1000$ (Kalahari Gemsbok National Park). 


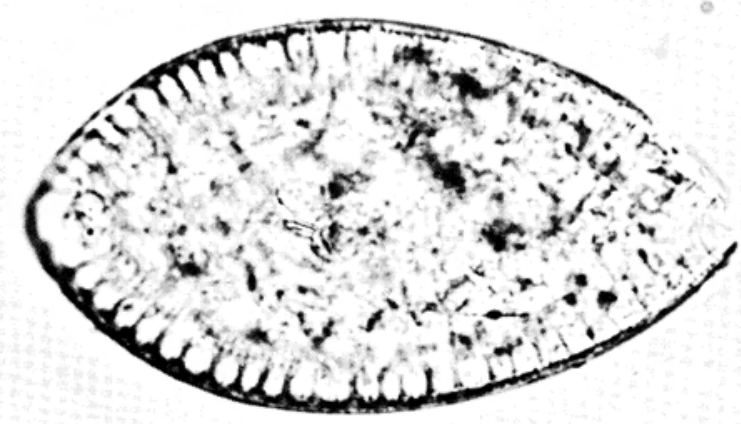

Fig. 8 (c). Surirella $\times 1000$ (Kalahari Gemsbok National Park). $\quad$ Photos: C. S. MacRae

\section{Gordonia Formation}

Sand is the most widespread deposit in the park. Along river courses, around some pans and in some of the "streets" between dunes it is white, while the dunes themselves consist of a bright reddish sand. Local variations in colour may occur, usually shades of yellow or brown. The redness of the dune sand is due to a deposit of iron oxide around the grains of sand. It has been observed that redness of dunes increases with age and distance of transport (Walker 1979). If the source of the sand does not change, then these factors indicate that the iron is derived from the dunes themselves. The iron-rich minerals magnetite, haematite and ilmenite were found among the other heavy minerals such as garnet, rutile, tourmaline and zircon.

The white sand is located where water collected or flowed. The iron oxides have been leached from the sand to leave white quartz and feldspar.

The Gordonia Formation normally overlies the fairly even surface of the Mokalanen Formation.

Geomorphological aspects

Although Breed, Fryberger, Andrews, McCawley, Lennartz, Gebel \& Harstman (1979) describe the dunes in the park as linear dunes together with some compound linear ones, a closer inspection reveals an interrelationship of different dune-types which requires further study.

The simple linear dunes are well-developed near the river beds, but further away they become at least partially transverse with a tendency to form barchanoid ridges in places. The spacing of the troughs ("streets") decreases sharply away from the river beds. Some areas are virtually free from dunes or are only gently undulating (Bothma \& De Graaff 1973a). In a number of localities Bothma \& De Graaff (1973a, 1973b) reported irregular dunes. They are younger transverse dunes with barchanoid ridges formed in spots where older stabilised sands had become loose 


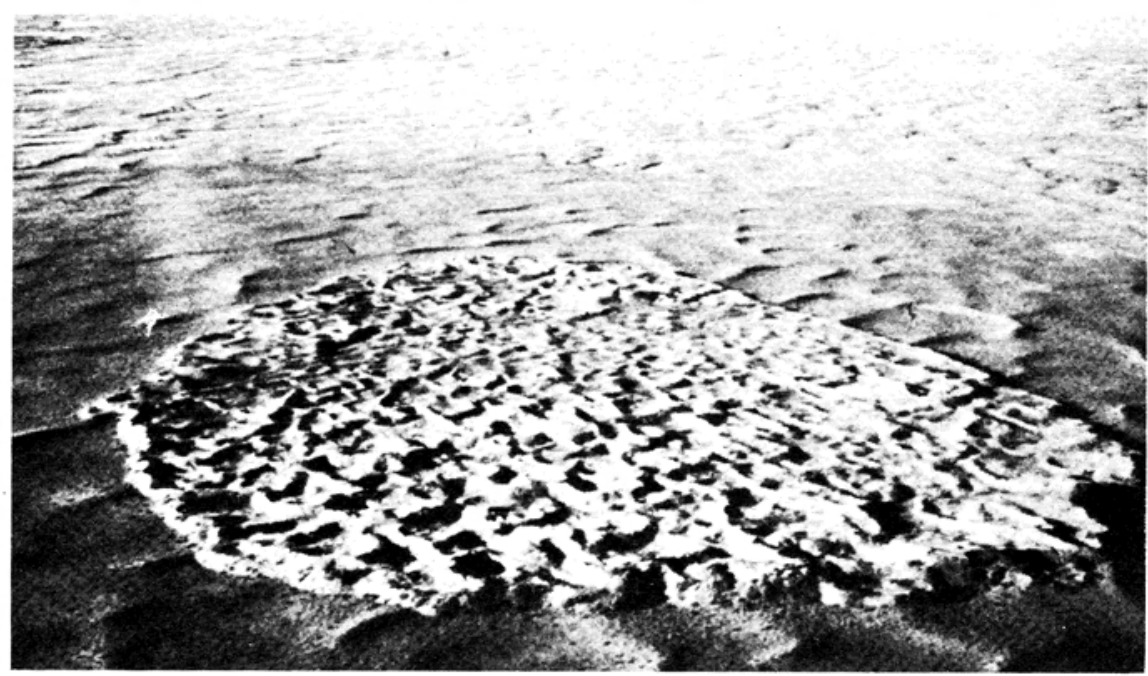

Fig. 9. Younger dunes in the Gordonia Formation (Kalahari Gemsbok National Park).

Photo: J. du P. Bothma.

again (Fig. 9), probably as a result of the loss of vegetation - or where younger sands with different grain sizes were blown over older sands.

The park, without the sand cover, can be considered to be a young plateau where vertical erosion by the rivers stopped as a result of the onset of desert conditions. The Nossob River received enough water at one stage to become a mature river; it formed meanders inter alia near Rooikop and Kwang and even some oxbow lakes near Grootbrak (Fig. 1). Vertical erosion then resulted in the formation of terraces slightly above the present river level. Unconsolidated gravels are found in places on the river banks.

Many incipient pans can be recognised among the dunes. Some of the pans e.g. at Langklaasdam and Kwang (Fig. 1) formed when the flow of the Nossob River could not remove the sand load fast enough. The tributaries dammed against the higher base level of the Nossob River and formed pans. The pans away from the rivers have probably formed by deflation (Lancaster 1979) and have deepened by wind action and to a smaller extent by the effect of animals on the pan floors i.e. trampling of the pan floors to dust, to be blown away or carrying material away after a mudbath.

\section{Geological history}

A dissected topography with a general drainage direction towards the present Botswana existed during the Miocene period (Thomas 1981). These river valleys were filled by sandy clay which becomes richer in sand higher upwards in the succession. Braided streams eroded parts of their floors and redeposited the material as poorly rounded and sorted conglomerates. During a drier period at the end of the Tertiary (Thomas 1981) duricrust in the form of calcrete and silcrete formed. Ward, Seely \& Lancaster (1983), date this episode as late Miocene. Scree was cemented by the calcrete to form conglomerate. 
During the early Quaternary wetter weather caused active erosion by rivers with a drainage towards the south and the solution of basins in the calcrete. During drier periods wind action excavated pans. The maximum depth of the pans is determined by the depth of the water table. During a very arid period sand was blown in to cover the whole area but episodic rains were enough for the rivers to keep their channels clear of sand.

During a recent wet phase or phases from approximately 19000 years B.P. to 12000 years B.P. (Heine 1978) diatoms and molluscs flourished in the pans and accumulated in the clayey and calcareous pan deposits to form readily identifiable beds. During a later period of aridity the prevailing winds formed most of the linear dunes as they are known today. The filling of the Nossob riverbed between Kaspersdraai and Union's End probably occurred during this time. It was probably a result of the river dumping its load of sand when it did not have enough water to flow any further and the filling of the river course by windblown sand.

The present wetter period keeps the vegetation and consequently the sand stabilised.

\section{Acknowledgements}

The author wishes to thank the Director of the Geological Survey of the Republic of South Africa for permission to publish this paper. The National Parks Board of Trustees is thanked for facilities extended during field surveys. Mr. and Mrs. E. A. N. le Riche evened out many wrinkles in a friendly and capable way. The following members of the Geological Survey merit special mention: Dr. P. J. Smit and Mr. E. H. Stettler for discussions on underground water and the interpretation of geomagnetic data; Dr. R. J. and Mrs. M. A. Thomas for their pioneering geological mapping; Dr. A. W. Keyser and his staff for preparing the samples of diatoms; Dr. A. W. Keyser, Dr. F. Walraven, Mr. M. Köhler and Mr. C. S. MacRae for the preparation of slides and photographs; Mrs. A. E. J. Thiart for compiling the map and typing the manuscript; and finally Dr. M. R. Johnson for critical reading of the manuscript.

\section{REFERENCES}

BOTHMA, J. DU P. and G. DE GRAAFF. 1973a. A habitat map of the Kalahari Gemsbok National Park. Koedoe 16:181-188.

BOTHMA, J. DU P. and G. DE GRAAFF. 1973b. Strange dunes in the Kalahari Gemsbok National Park. Custos 3(1): 34-36.

BREED, C. S., S. C. FRYBERGER, S. ANDREWS, C. McCAWLEY, F. LENNARTZ, D. GEBEL and K. HARSTMAN. 1979. Regional studies of sand seas, using Landsat (ERTS) Imagery 305-397. In: McKEE, E. D. (Ed.) A study of global sand seas. United States Government Printing Office, Washington, D.C.

HEINE, K. 1978. Radiocarbon chronology of Late Quaternary lakes in the Kalahari, southern Africa. Catena 5: 145-149. 
LANCASTER, I. N. 1979. Quaternary environments in the arid zone of southern Africa. Environmental studies, occasional paper 22. University of the Witwatersrand, Johannesburg.

NETTERBERG, F. 1978. Dating and correlation of calcretes and other pedocretes. Trans. geol. Soc. S. Afr. 81: 379-391.

NETTERBERG. F. 1980. Geology of southern African calcretes. Trans. geol. Soc. S. Afr. 83: 255-284.

SMIT, P. J. 1962. Geohidrologiese verkenning: Nasionale Kalahari Gemsbokpark. Unpubl. report Geol. Surv. S. Afr.

SMIT, P. J. 1964. Die geohidrologie van die Nasionale Kalahari Gemsbokpark. Unpubl. report Geol. Surv. S. Afr.

SMIT, P. J. 1972. The Karoo system in the Kalahari of the northern Cape Province. Ann. Geol. Surv. S. Afr. 9: 79-81.

THOMAS, M. A. 1981. The geology of the Kalahari in the northern Cape Province (Areas 2620 and 2720). M.Sc. thesis. University Orange Free State, Bloemfontein.

WALKER, T. R. 1979. Red color in dune sand. In: McKEE, E. D. (Ed.) A study of global sand seas. United States Government Printing Office, Washington, D.C.

WARD, J. D., M. K. SEELY and I. N. LANCASTER. 1983. On the antiquity of the Namib. S. Afr. J. Sci. 79: 175-183. 